\title{
PENGARUH PEMBERIAN BEBERAPA JENIS HIJAUAN TERHADAP PERFORMANS TERNAK KELINCI
}

\author{
Chelry S. Mas'ud*; Y.R.L. Tulung;**, J. Umboh;**, C.A. Rahasia** \\ Fakultas Peternakan Universitas Sam Ratulangi, Manado 95115
}

E-mail : chelrymasud@yahoo.com

\begin{abstract}
ABSTRAK
Produksi ternak kelinci memiliki potensi yang sangat besar di Negara Negara berkembang karena dapat mengkonsumsi hasil-hasil ikutan pertanian menjadi produk daging. Penelitian ini bertujuan untuk mengetahui sejauh mana pemberian daun wortel, daun kubis, dan daun kangkung, kombinasi antar satu hijauan dengan hijauan lainnya serta kombinasi ketiga hijauan atau sayuran tersebut terhadap performa ternak kelinci. Materi yang digunakan dalam penelitian ini adalah kelinci lokal sebanyak 21 ekor kelinci lepas sapih dengan bobot badan awal \pm 300 -400gram/ekor, kandang metabolik serta peralatan kandang. Rancangan percobaan yang digunakan adalah Rancangan Acak Lengkap (RAL) dengan 7 perlakuan dan 3 ulangan, yaitu: $(\mathrm{R} 1)=$ Daun Wotel $(\mathrm{DW})+$ Konsentrat $(\mathrm{K}) ; \quad(\mathrm{R} 2)=$ Daun Kangkung (DK)+Konsentrat (K); (R3) = Daun Kubis $(\mathrm{Dku})+$ Konsentrat $(\mathrm{K}) ;(\mathrm{R} 4)=$ Daun Wortel (DW), Daun Kubis (Dku)+Konsentrat $(\mathrm{K}) ;(\mathrm{R} 5)=$ Daun Kubis $(\mathrm{Dku})$, Daun Kangkung (DK) + Konsentrat (K); (R6) = Daun Wortel (DW), Daun Kangkung (DK) + Konsentrat (K); (R7) = Daun Wortel (DW), Daun Kangkung (DK), Daun Kubis (Dku) + Konsentrat (K). Peubah yang diamati adalah konsumsi pakan, pertambahan bobot badan dan konversi pakan kelinci. Hasil penelitian menunjukkan bahwa pemberian beberapa jenis hijauan tidak berpengaruh nyata $(\mathrm{P} \geq 0.05)$ terhadap konsumsi pakantetapi memberikan pengaruh sangat nyata $(\mathrm{P} \leq 0.01)$ terhadap pertambahan bobotdan konversi pakan ternak kelinci. Kesimpulan dari penelitian ini adalah pemberian hijauan Daun Wortel (DW)
\end{abstract}

\footnotetext{
*Alumni Fakultas Peternakan Unsrat

**Jurusan Nutrisi dan Makanan Ternak
}

dikombinasikan dengan Daun Kangkung (DK) memberikan hasil terbaik dilihat dari aspek konsumsi zat-zat makanan, pertambahan bobot dan konversi pakan ternak kelinci.

Kata Kunci :Kelinci, Konsumsi Pakan, Pertambahan Bobot Kelinci

\section{ABSTRACT}

THE FFECT OF SOME TYPES OF FORAGE FOR LIVESTOCK PERFORMANCE RABBIT. Rabbit productions may have considerable potential in developing counties as a means of converting forages and agricultural by product to meat. The present study was conductes to laborate leaves, and their combinations in the diets on rabbit performance. Twenty one 6week old weaned rabbits, weighing 300-400 gramns were used in this trial. Animals were put in individual metabolic crates. A Completely Randomized Design with 7 treatments and 3 replications was used as an experimental design and Tukey test was employed to determine treatmen differences. Treatments were arranged as: R1 : carrot leaves + concentrate; R2 : kale leaves + concentrate; R3 : cabbage leaves + concentrate; R4 : carrot and cabbage leaves + concentrate; R5 : kale and cabbage leaves + concentrate; R6 carrot and kale leaves; R7 : carrot + kale + cabbage leaves + concentrate. Parameters measured were; daily feed consumption, daily gain, and feed conversion ratio. Research result showed that treatments significantly affected daily feed consumption, daily gain, and feed convertion ration be concluded that the combination of carrot and cabbage leaves can support rabbit performance in the present study. 
Keywords : Rabbit, daily feed consumption, daily gain, feed convertion ratio.

\section{PENDAHULUAN}

Kelinci merupakan ternak kecil dan digolongkan sebagai ternak herbivora non ruminansia. Usaha ternak kelinci sederhana mudah dilaksanakan dan diharapkan dapat memenuhi sebagian kebutuhan protein hewani masyarakat. Ternak kelinci adalah salah satu komoditas peternakan yang dapat menghasilkan daging berkualitas tinggi (Kartadisastra 1997), dimana struktur dagingnya lebih halus, warna dan bentuk yang menyerupai daging ayam dengan persentase karkas cukup tinggi, yaitu dapat mencapai 50 persen. Kandungan protein daging kelinci $18,7 \%$, kadar lemak lebih rendah $(6,2 \%)$, jika dibandingkan dengan lemak daging sapi yang dapat mencapai $18,3 \%$ sedang lemak domba 17,5\% (Rukmana, 2005).

Menurut (Rasyaf 1996) pakan merupakan faktor terpenting dalam usaha peternakan yang menentukan produktivitas ternak. Untuk menjamin supaya kelinci dapat berproduksi dengan baik, sangat dibutuhkan pakan dalam jumlah cukup yang mengandung karbohidrat, protein, lemak, mineral, vitamin dan air. Pakan yang akan diberikan harus baik dan jelas kualitasnya serta dapat memenuhi kebutuhan nutrisi dari kelinci. Kelinci pada masa pertumbuhan membutuhkan Digestible Energy (DE) 2500kkal $/ \mathrm{kg}$, TDN $65 \%$, serat kasar $10=12 \%$, protein kasar 16\% dan lemak 2\% (NRC, 1977). Tersedianya hijauan berupa rumput, leguminosa, berbagai jenis hijauan seperti daun wortel, daun kangkung, dan daun kubis serta limbah pertanian seperti dedak, onggok, ampas tahu dan jenis hijauan dan sayuran lainnya di daerah beriklim tropis seperti Indonesia, merupakan potensi yang dapat dimanfaatkan sebagai bahan pakan kelinci, serta ekonomis dan tidak bersaing dengan kebutuhan manusia. Kelinci dapat menggunakan protein hijauan secara efesien, reproduksi tinggi, efesiensi pakan yang tinggi dan hanya membutuhkan pakan dalam jumlah sedikit (Farel dan Raharjo,1984).

Beberapa jenis hijauan seperti daun wortel, daun kangkung, dan daun kubis dan mempunyai peranan yang besar bagi ternak kelinci untuk memenuhi kebutuhan hidup maupun untuk berproduksi. Pakan hijauan untuk kelinci dapat dipilih dari rerumputan, dedaunan yang batangnya halus dan lunak, seperti rumput lapangan dan sayuran yang kaya protein dan vitamin (Cheeke, 1987). Pemberian pakan kelinci berdasarkan pada bobot kelinci dan status fisiologis. Kebutuhan bahan kering untuk kelinci adalah 3-3,5\% bobot kelinci. 
Sedangkan NRC (1977) menunjukkan bahwa kebutuhan pakan kelinci yaitu $60 \mathrm{~g}$ per kg bobot per/hari.

\section{MATERI DAN METODE PENELITIAN}

Penelitian ini dilaksanakan di laboratorium lapang Jurusan Ilmu Nutrisi dan Makanan Ternak Fakultas Peternakan Universitas Sam Ratulangi Manado, Penelitian ini dilaksanakan selama 6 minggu dari tanggal 1 Juni 2014 sampai dengan 16 Juli 2014, dengan adaptasi pakan selama 14 hari dari tanggal 1 Juni 2014 sampai dengan 14 Juni 2014, dilanjutkan dengan perhitungan konsumsi pakan dan pertambahan bobot badan kelinci selama 32hari. Kelinci yang digunakan berumur 1,5 bulan (lepas sapih) "Unsexed" dengan bobot badan antara $\pm 300-400$ g. Kandang yang digunakan adalah kandang metabolik berisikan satu ternak dalam satu ruang yang dilengkapi dengan lampu, tempat makan dan tempat minum. Bahan pakan penyusun ransum terdiri dari beberapa jenis hijauan seperti daun wortel, daun kangkung, daun kubis dan konsentrat dapat dilihat pada Tabel 1.

$$
\text { Penelitian ini menggunakan }
$$

RancanganAcak Lengkap (RAL) (Steel dan Torrie, 1993) dengan 7 (tujuh) perlakuan pakan hijauan dengan 3 (tiga) kali ulangan. Perlakuan yang diberikan yaitu R1 = 70\% (DW) $+30 \%(\mathrm{~K}) ; \mathrm{R} 2=$ $70 \%(\mathrm{DK})+30 \%(\mathrm{~K}) ; \mathrm{R} 3=70 \%(\mathrm{Dku})+$ $30 \%(\mathrm{~K}) ; \mathrm{R} 4=35 \%(\mathrm{DW}), 35 \%(\mathrm{Dku})+$ $30 \%(\mathrm{~K}) ; \mathrm{R} 5=35 \%(\mathrm{DK}), 35 \%(\mathrm{Dku})+$ $30 \%(\mathrm{~K}) ; \mathrm{R} 6=35 \%(\mathrm{DW}), 35 \%(\mathrm{DK})+$ $30 \%(\mathrm{~K}), \mathrm{R} 7=23.3 \%(\mathrm{DW}) 23.3 \%(\mathrm{DK})$ $+23.3 \%(\mathrm{Dku})+30 \%(\mathrm{~K})$. Pemberian pakan di mulai dengan masa adaptasi selama 14 hari dan pengumpulan data 32 hari, Variabel yang diukur adalah konsumsi pakan, pertambahan bobot badan kelinci dan konversi pakan. Komposisi Komposisi zat-zat makanan pakan ransum percobaan.

Tabel 1. Kandungan Nutrisi Bahan Pakan Penelitian

\begin{tabular}{lcccccc}
\hline \multirow{2}{*}{ Bahan Pakan } & \multicolumn{6}{c}{ Kandungan Nutrisi dalam 100\% BK } \\
\cline { 2 - 7 } & Air & Abu & Protein & Lemak & $\begin{array}{c}\text { Serat } \\
\text { Kasar }\end{array}$ & Karbohidrat \\
\hline Daun Wortel & 86.22 & 2.66 & 3.61 & 0.23 & 1.38 & 5.90 \\
Daun Kangkung & 92.79 & 1.07 & 2.81 & 0.20 & 0.20 & 2.93 \\
Daun Kubis & 93.64 & 0.29 & 1.26 & 1.26 & 1.73 & 1.65 \\
Konsentrat & 10.78 & 6.81 & 13.21 & 8.28 & 4.44 & 56.57 \\
\hline
\end{tabular}

Sumber : Balai Riset Dan Standarisasi Industri Manado 2014 
Tabel 2. Komposisi zat-zat makanan pakan percobaan

\begin{tabular}{lllllll}
\hline \multirow{2}{*}{ Perlakuan } & \multicolumn{5}{c}{ Bahan kering, Karbohidrat dan zat-zat makanan*) } \\
\cline { 2 - 7 } & BK & PK & SK & LK & KH & Abu \\
\hline R1 & 36.412 & 6.490 & 2.298 & 2.645 & 21.101 & 3.905 \\
R2 & 31.813 & 5.930 & 1.472 & 2.624 & 19.022 & 2.792 \\
R3 & 31.218 & 4.845 & 2.543 & 3.366 & 18.126 & 2.246 \\
R4 & 31.516 & 5.668 & 2.421 & 3.006 & 19.614 & 3.076 \\
R5 & 31.516 & 5.388 & 2.008 & 2.995 & 18.574 & 2.519 \\
R6 & 34.113 & 6.210 & 2.107 & 2.635 & 20.062 & 3.349 \\
R7 & 33.147 & 5.755 & 2.104 & 2.878 & 19.416 & 2.981 \\
\hline
\end{tabular}

*) Dihitung bedasarkan kandungan nutrisi bahan pakan penelitian hasil analisis Balai Riset Dan Standarisasi Industri Manado 2014.

\section{HASIL DAN PEMBAHASAN}

Rataan Konsumsi Bahan Kering, Pertambahan Bobot Badan dan Konversi Pakan selama penelitian dapat dilihat pada Tabel 3.

\section{Konsumsi}

Hasil analisis varians konsumsi bahan kering ransum perlakuan selama penelitian menunjukkan tidak ada pengaruh nyata $(\mathrm{P} \geq 0,05)$. Menurut (Tilman dkk., 1991) bahwa ransum yang mempunyai kandungan protein, energi dan bahan kering yang sama maka akan menyebabkan konsumsi bahan kering sama pula. Hal ini diduga karena umur ternak yang hampir sama. Lebih lanjut Anggorodi (1995) menyatakan bahwa konsumsi ransum dipengaruhi oleh kesehatan ternak, palatabilitas, mutu ransum dan cara pemberian ransum. Hasil analisis varians menunjukkan bahwa konsumsi karbohidrat antar perlakuan selama penelitian menunjukkan tidak berbeda nyata $(\mathrm{P} \geq 0,05)$.

Tabel 3. Rataan Konsumsi Bahan Kering, Pertambahan Bobot Badan dan Konversi Pakan selama penelitian $\left(\right.$ g.ekor ${ }^{-1} \cdot$ hari $\left.^{-1}\right)$.

\begin{tabular}{lccccccc}
\hline Variabel & \multirow{2}{*}{ R1 } & R2 & R3 & R4 & R5 & R6 & R7 \\
\hline Konsumsi & 127,99 & 108,22 & 106,61 & 116,49 & 107,36 & 118,85 & 143,49 \\
\hline PBB & $39.81^{\mathrm{c}}$ & $20.22^{\mathrm{ab}}$ & $31.09^{\mathrm{bc}}$ & $33.75^{\mathrm{bc}}$ & $26.56^{\mathrm{bc}}$ & $42.33^{\mathrm{c}}$ & $22.84^{\mathrm{ab}}$ \\
\hline Konversi & $3.251^{\mathrm{a}}$ & $5.341^{\mathrm{ab}}$ & $3.487^{\mathrm{a}}$ & $3.688^{\mathrm{a}}$ & $4.166^{\mathrm{ab}}$ & $2.822^{\mathrm{a}}$ & $6.256^{\mathrm{b}}$ \\
\hline
\end{tabular}

Ket: nilai dengan superskrip yang berbeda pada baris yang sama menunjukkan perbedaan yang nyata $(\mathrm{P} \geq 0.01)$. 
Kandungan energi dalam ransum berpengaruh pada konsumsi ternak, hal ini sesuai dengan pendapat Wahju (1997), bahwa tingkat energi dalam ransum menentukan banyaknya pakan yang dikonsumsi.

\section{Pertambahan Bobot Badan}

Hasil analisis varians menunjukkan bahwa pemberian hijauan secara tunggal maupun kombinasi berbeda sangat nyata $(\mathrm{P} \geq 0,01)$ terhadap pertambahan bobot kelinci lokal.

Hasil uji BNJ menunjukkan bahwa pertambahan bobot badan kelinci ditunjukkan perlakuan R6. Hal ini mengindikasikan bahwa daun wortel dikombinasikan bersama daun kangkung lebih memberikan kecukupan zat-zat makanan, khususnya protein kasar yang dimiliki kedua bahan pakan tersebut. Hasil analisis proksimat perlakuan R6 (daun wortel dan daun kangkung ditambah konsentrat) memiliki kandungan protein lebih tinggi dan serat kasar rendah. Salah satu nutrient yang berpengaruh adalah protein. Di dalam tubuh, protein digunakan untuk pertumbuhan dan berperan untuk kenaikan bobot ternak, sedangkan konsumsi serat kasar yang tinggi dapat menurunkan bobot ternak (Anggrodi, 1995). Bobot ternak berbanding lurus dengan tingkat konsumsi pakannya. Hal ini berarti bahwa konsumsi pakan akan memberikan gambaran nutrien (protein, lemak dan karbohidrat) yang didapat sehingga mempengaruhi bobot ternak (Kartadisastra, 1997).

\section{Konversi Pakan}

Hasil analisis varians angka konversi pakan antar perlakuan selama penelitian menunjukkan perbedaan yang sangat nyata $(P \geq 0,01)$.

Uji lanjut BNJ menunjukkan bahwa angka konversi yang terendah (terbaik) ditampilkan oleh perlakuan R6 (Daun Wortel, Daun Kangkung + Konsentrat). Hal ini disebabkan ternak kelinci pada perlakuan ini memberikan angka pertambahan bobot yang tertinggi dibandingkan dengan perlakuan lainnya. Sesuai dengan pernyataan (Rasyaf 1997) semakin baik mutu ransum yang diberikan maka semakin kecil pula angka konversinya. Konversi pakan menggambarkan kualitas suatu pakan, pertambahan bobot dan tingkat konversi pakan Mujiasih (2002).

\section{KESIMPULAN}

Pemberian hijauan Daun Wortel dikombinasikan dengan Daun Kangkung memberikan hasil terbaik dilihat dari aspek konsumsi zat-zat makanan, pertambahan bobot dan konversi pakan ternak kelinci. 


\section{DAFTAR PUSTAKA}

Anggorodi, R., 1995. Ilmu Makanan Ternak Umum. PT Gramedia. Jakarta.

Cheeke. P.S.R. 1987. Rabbit Feeding \& Nutrition Departement of Animal Science Oregon State University, Corvallis.

Farrell, D.J. dan Y.C. Raharjo. 1984. Potensi ternak kelinci sebagai penghasil daging. Pusat Penelitian dan Pengembangan Ternak, Bogor.

Kartadisastra, H. R., 1997. Ternak Kelinci Teknologi Pascapanen. Kanisius.Yogyakarta.

Mujiasih , 2002. Performan Ayam Broiler yang Diberi Antibiotik Zine Bacitracin, Probiotik Bacilus sp dan Berbagai Level Saccharomyces cerevisaea dalam Ransumnya.Institut Pertanian Bogor.

NRC.1977. Nutrient Requirment of Rabbit. $2^{\text {nd }}$ Ed. National Academy of Sciences, Washington D.C. p 10.
Parakkasi, A. 1999. Ilmu Makanan dan Ternak Ruminansia. UI Press, Jakarta.

Rasyaf, M., 1996. Memasarkan Hasil Peternakan. Penebar Swadaya. Jakarta.

1997. Penyajian Makanan Ayam Petelur. Kanisius. Yoyakartra.

Rukmana. H.,R 2005. Prospek Beternak Kelinci. http://www.suarakaryaonline.com/news.

Steel, R. C. dan J.H Torrie. 1993. Prinsip dan Prosedur Statistika. Gramedia Pustaka Utama. Jakarta.

Tilman, A.D., H. Hartadi., S. Reksohadiprodjo., S. Prawirokusumo, dan S. Lebdosoekojo. 1991. Ilmu Makanan Ternak Dasar. Gadjah Mada University. Yogyakarta.

Wahju, J. 1997. Ilmu Nutrisi Unggas. Gadjah Mada University. Yogyakarta. 